\title{
Sifat fisik makanan padat (foodbar) berbasis tepung komoditas lokal
}

\author{
Anni Nuraisyah ${ }^{1^{*}}$, Tirto Wahyu Widodo ${ }^{2}$, Christa Dyah Utami ${ }^{3}$
}

\author{
$1^{*}$ Jurusan Produksi Pertanian Politeknik Negeri Jember \\ 2 Jurusan Produksi Pertanian Politeknik Negeri Jember \\ 3Jurusan Produksi Pertanian Politeknik Negeri Jember \\ *Corresponding Author email: anni.nuraisyah@polije.ac.id
}

\begin{tabular}{|c|c|}
\hline & Abstrak \\
\hline Diterima & Konsumsi makanan cepat saji secara terus menerus dapat merugikan kesehatan manusia. \\
\hline Bulan Januari & Solusi efektif yaitu dengan membuat makanan inovatif yang mampu memenuhi \\
\hline 2020 & $\begin{array}{l}\text { kecukupan gizi salah satunya yaitu foodbar. Bahan baku yang digunakan dalam } \\
\text { pembuatan foodbar berasal dari komoditas lokal yang ditepungkan, antara lain ubi jalar, } \\
\text { kacang hijau dan kelor serta ditambahkan porang untuk menyatukan ketiga bahan }\end{array}$ \\
\hline Diterbitkan & tersebut. Tepung ubi ubi jalar kuning mengandung karbohidrat $77,7 \%$ dengan nilai cerna \\
\hline Bulan Februari & tinggi $(98 \%)$, sedangkan tepung daun kelor mengandung protein 27,1 gram/ 100 gram. \\
\hline 2020 & $\begin{array}{l}\text { Tepung kacang hijau digunakan sebagai pemberi cita rasa, sedangkan tepung porang yang } \\
\text { kaya dengan glukomannan berperan sebagai binder agent untuk menghasilkan produk } \\
\text { foodbar yang tidak mudah hancur. Perlakuan pada penelitian ini dengan menggunakan }\end{array}$ \\
\hline Keyword & dua faktor, yaitu komposisi tepung komposit dan komposisi penambahan porang. \\
\hline & Pengamatan yang dilakukan yaitu sifat fisik meliputi kadar air, ekspansi volume, densitas \\
\hline $\begin{array}{l}\text { komoditas lokal, } \\
\text { ubi jalar, kacang } \\
\text { hijau, kelor }\end{array}$ & $\begin{array}{l}\text { kamba dan tekstur dari foodbar. Perlakuan terbaik pada foodbar pada kombinasi } \\
\text { perlakuan } 100 \text { gram tepung ubi jalar kuning ( } 40 \text { gram) tepung kacang hijau ( } 60 \text { gram) } \\
\text { tepung daun kelor dan }(4 \% \text { ) porang (P3T1). }\end{array}$ \\
\hline
\end{tabular}

\section{PENDAHULUAN}

Konsumsi makanan masyarakat Indonesia kini cenderung kearah makanan cepat saji (junk food) dibandingkan dengan makanan pokok padat gizi. Padahal, konsumsi makanan cepat saji secara terus menerus dapat merugikan kesehatan manusia secara umum sebab banyaknya kandungan zat aditif serta sistem pemasakan yang tidak sehat. Oleh sebab itu, konsumsi makanan cepat saji menjadi salah satu produk pangan yang dibatasi penggunaannya.

Solusi efektif dalam mengurangi konsumsi makanan cepat saji adalah dengan membuat sebuah produk pangan inovatif yang dapat memenuhi kecukupan gizi dan tidak membahayakan kesehatan, salah satunya adalah produk pangan foodbar. Foodbar adalah produk pangan berbentuk padat, bertekstur tidak mudah hancur, kandungan gizi makro seimbang, tahan lama, siap konsumsi, dan bisa dinikmati berbagai kalangan sehingga sangat cocok dikembangkan di masyarakat.

Bahan baku lokal yang dapat dibuat menjadi foodbar adalah umbi-umbian dan kacangkacangan. Berdasarkan dua kelompok tanaman tersebut, bahan pangan lokal yang berpotensi untuk dikembangkan menjadi bahan baku foodbar adalah tepung ubi jalar kuning, daun kelor, porang, dan kacang hijau. Tepung ubi ubi jalar kuning mengandung karbohidrat $77,7 \%$ dengan nilai cerna tinggi (98\%), sedangkan tepung daun kelor mengandung protein 27,1 gram/ 100 gram. Tepung kacang hijau digunakan sebagai pemberi cita rasa, sedangkan tepung porang yang kaya dengan glukomannan berperan sebagai binder agent untuk menghasilkan produk foodbar yang tidak mudah hancur.

Berdasarkan fungsi masing-masing dari keempat bahan pangan lokal tersebut, maka sangat layak untuk dijadikan bahan baku pembuatan foodbar. Namun demikian, informasi mengenai komposisi yang tepat untuk membuat foodbar yang berkualitas secara fisik dan organoleptik masih belum ada. Oleh karena itu, perlu dilakukan penelitian untuk mendapatkan komposisi tepung komposit yang paling tepat dalam menghasilkan foodbar yang berkualitas, baik secara fisik maupun organoleptik.

\section{LANDASAN TEORI}

\section{Foodbar}

Foodbar adalah produk pangan yang diformulasikan untuk menyediakan energi bagi pekerja fisik dengan kadar gula darah rendah, sehingga cocok bagi penderita hypoglycemia. Foodbar sangat bagus untuk sekolah, organisasi dan kantor perencanaan dalam menghadapi bencana, juga untuk pendakian, perkemahan dan acara lainnya. Selain itu, dapat pula digunakan untuk bermacam-macam situasi gawat seperti bertahan 
hidup di lautan, siap siaga saat gempa bumi, dan keadaan bencana lainnya (Datrex, 2009).

Setiap 16 ons foodbar setara dengan 400 kalori tiap sajian. Konsumsi yang dianjurkan adalah 3 sajian tiap orang per hari yang setara dengan 1200 kalori. Setiap 2400 kalori foodbar dikemas sendirisendiri dengan alumunium foil untuk menjaga dari serangga (Datrex, 2009). Selain itu, pengawasan ketat juga dilakukan dalam pembuatannya untuk memastikan hasil dengan kualitas terbaik.

Emergency foodbar khusus dibuat menjadi makanan yang memiliki kandungan protein dan vitamin tinggi, sehingga setiap bar berisi cukup nutrisi untuk dikonsumsi. Biasanya foodbar dikemas 9 satuan dalam satu tempat sehingga dapat dimakan untuk sarapan, makan siang dan makan malam selama 3 hari sebagai makanan dalam kondisi bencana. Rata-rata dalam satu hari masa bencana, foodbar akan mencukupi tubuh dengan 1200 kalori. Pada kondisi stress saat bencana, foodbar sangat baik sebagai suplemen makanan (Liz, 2009).

\section{Bahan Baku Foodbar}

Bahan pangan lokal dapat dijadikan sebagai bahan baku pembuatan foodbar. Bahan pangan lokal berupa umbi-umbian dan kacangkacangan memiliki potensi yang sangat baik bahan baku foodbar. Jenis bahan pangan lokal tersebut diantaranya adalah ubi jalar kuning, daun kelor, porang, dan kacang hijau. Keempat bahan pangan tersebut memiliki kandungan gizi dan fungsi yang berbeda, sehingga campuran keempatnya akan menghasilkan foodbar yang sangat baik.

Ubi jalar kuning kaya antioksidan (beta karoten dan vitamin C), vitamin B kompleks, besi, dan juga fosfor. Kandungan pati dan serat pada ubi jalar kuning usia panen 120 hari masing-masing sebesar 20,7\% dan 1,3\% (Antarlina, 1991). Ubi jalar kuning mengandung protein dan lemak cukup rendah, yakni sebesar 1,1 gram dan 0,4 gram tiap 100 gram. Kandungan gula ubi jalar kuning antara 2,0-6,7\% dan amilosa sebesar 9,8-26\%. Kandungan gula yang tinggi memberi rasa manis yang kuat, sedangkan amilopektin memberikan sifat lunak.

Daun kelor (Moringa oleifera) dapat dimanfaatkan sebagai bahan pangan, obat-obatan, maupun pakan ternak (Becker, 2003). Daun kelor kaya akan kandungan karotenoid, asam askorbat, zat besi (Richter, et al. 2002), vitamin A dan B, kalsium, serta tinggi protein (Becker, 2003). Tepung daun kelor mengandung protein 27,1 g, karbohidrat 38,2 $\mathrm{g}$, serat 19,2 g, kalsium $368 \mathrm{mg}$, dan besi 28,2 mg tiap 100 gram bahan (Fuglie, 2011).
Porang (Amorphophallus oncophyllus) dapat dibuat menjadi tepung dan jel dengan nama konyaku dan shirataki. Tepung porang dapat menjadi alternatif pengganti tepung terigu sebagai sumber karbohidrat (Wijanarko, 2007). Tepung porang terdiri dari sebagian besar polisakarida dan hidrokoloid, yaitu glukomanan. Kandungan glukomanan tepung porang mencapai $64,98 \mathrm{~g} / 100 \mathrm{~g}$ bahan (Arifin, 2001; Eri, 2007). Glukomanan merupakan suatu senyawa yang memiliki kemampuan sebagai bahan pengikat (binding agent). Tepung porang sebagai bahan pengikat telah dimanfaatkan dalam pembuatan beras tiruan dari tepung ubi jalar dan ubi kayu (Erliyati, 2008). Selain itu, tepung porang juga kaya akan kandungan serat yang larut air (water solable dietary fiber) (Wang dan Johnson, 2007).

Kacang hijau yang dibuat tepung dapat digunakan untuk membuat aneka kue basah, kue tradisional, kembang gula dan makaroni. Tepung kacang hijau sangat kaya asam amino lisin tetapi miskin metionin dan sistein. Sebaliknya tepung beras dan sereal lainnya sangat miskin lisin tapi kaya metionin dan sistein (Astawan, 2004). Kadar gizi tepung kacang hijau relatif tidak berubah terutama kandungan proteinnya. Kandungan protein, karbohidrat, dan serat tepung kacang hijau masingmasing sebesar $19,09 \%, 72,86 \%$, dan $2,79 \%$ (Susanto dan Saneto, 1994).

\section{Proses Pembuatan Foodbar}

Foodbar dibuat melalui beberapa tahapan, yakni penyangraian, pencampuran, dan pengovenan. Penyangraian merupakan proses pengolahan tahap awal dimana produknya masih akan mengalami pengolahan lanjutan (Sholeh, 2009). Pada penyangraian (roasting), media pemindah panasnya adalah permukaan panas tanpa minyak sehingga sifatnya adalah pemanggangan. Hal tersebut yang membedakan dengan penggorengan yang menggunakan minyak sebagi media pemindah panas. Tujuan penyangraian adalah untuk mematikan mikroba yang tercampur dalam tepung agar nantinya tidak mengganggu mikroba yang hidup dalam ragi. Penyangraian tepung dilakukan hingga tepung berwarna kekuningkuningan sambil terus diaduk selama penyangraian agar panasnya merata dan tidak hangus (Suprapti, 2005).

Pencampuran adalah unit operasi dimana diperoleh ukuran yang seragam di satu atau lebih komponen, dengan menyebarkan komponen satu ke dalam komponen yang lain. Secara umum, pencampuran memiliki efek penting pada kualitas sensoris sehingga meningkatkan penerimaan konsumen dan keseragaman bahan pangan yang akan diproses lebih lanjut (Fellows, 1990). 
Pencampuran bertujuan untuk membentuk adonan yang dikehendaki. Pada tahap ini perlu diperhatikan tercapainya konsistensi pada adonan (Muchtadi dan Sugiyono, 1992). Pencampuran dilakukan dengan peralatan sederhana yang dioperasikan dengan tangan apabila jumlah adonannya sedikit dan bila jumlah besar maka menggunakan peralatan yang sesuai yaitu mixer (Maltz, 1992).

Pengovenan bertujuan untuk mengubah adonan yang mentah menjadi produk yang ringan, porous dan mudah dicerna. Pada awal pengovenan, pengembangan volume merupakan pengaruh fisik yang murni dari panas terhadap gas $\mathrm{CO}_{2}$ terjebak sehingga meningkatkan tekanan. Selama pemanggangan penetrasi panas terjadi di bagian bawah dan di atas. Penetrasi panas bagian tengah berjalan lambat, sehingga memudahkan terbentuk rongga udara dan pembentukan struktur crumb (Felows, 1990). Selama pengovenan, lemak mencair kemudian adonan terkondisikan dalam suatu gerakan sebagian berupa aliran konfersi dan sebagian lagi terhadap tekanan akumulasi dan perluasan gas karena pengaruh pemanasan (Felows, 1990).

\section{METODE PENELITIAN}

\section{Alat dan Bahan}

Alat yang digunakan untuk proses pembuatan tepung antara lain: Oven, mesin penggiling, timbangan, Loyang, kantong plastic, baskom, ayakan 100 mesh, pisau, kompor dan penggorengan. Alat-alat yang digunakan dalam pembuatan makanan padat (foodbar), antara lain: Timbangan analitik kapasitas 3100 g (OHAUS) untuk mengetahui massa bahan campuran, Mixer (Philips) sebagai alat homogenisasi, Blender (Sanyo) penghancur adonan kering, Alat pencetak (press hidrolik) digunakan untuk mencetak menjadi makanan padat, dan Wadah plastik. Sedangkan alat yang digunakan untuk analisa antara lain: Cawan petri sebagai wadah foodbar yang telah diketahui massanya untuk dioven, Termometer untuk mengetahui suhu foodbar setelah dioven, Timbangan analitik (Mettler AE 160 kapasitas maksimal $150 \mathrm{~g}$ ), Penetrometer untuk mengetahui daya patah foodbar, Desikator (SIMAX) untuk menurunkan kadar air bahan setelah dioven, oven dan penggaris.

Bahan baku utama yang digunakan dalam pembuatan tepung komposit sebagai bahan dasar foodbar yaitu ubi jalar kuning, kacang hijau dan daun kelor. Bahan yang digunakan dalam pembuatan foodbar antara lain, tepung porang (karagenan) diperoleh dari PT. Ambiko di JapananPasuruan, gula, margarin, susu bubuk, telur ayam petelur, baking powder.

Metode penelitian yang digunakan dalam penelitian ini adalah Rancangan Acak Kelompok yang disusun secara faktorial dan terdiri dari dua faktor, dimana faktor pertama terdiri dari 3 level dan faktor kedua terdiri dari 2 level. Serta aplikasi hukum "kekekalan massa" pada proses pembuatan produk dengan berbagai treatment yang dapat menghasilkan nilai yang representatif terhadap parameter yang diukur. Penelitian ini dianalisa dengan 3 kali ulangan. Perlakuan yang dicoba meliputi:

Faktor I: Jumlah tepung komposit (160 g)

P1 = tepung ubi jalar kuning : tepung daun kelor : tepung kacang hijau $=5: 2: 3$

P2 = tepung ubi jalar kuning : tepung daun kelor : tepung kacang hijau $=5: 2.5: 2.5$

P3 = tepung ubi jalar kuning : tepung daun kelor : tepung kacang hijau $=5: 3: 2$

Faktor II: Jumlah tepung porang

$\mathrm{T} 1=$ jumlah tepung porang 4 gram $(\mathrm{b} / \mathrm{b})$

$\mathrm{T} 2=$ jumlah tepung porang 8 gram $(\mathrm{b} / \mathrm{b})$

\section{Tahap Pembuatan Tepung}

Proses pembuatan tepung ubi jalar kuning dimulai dengan proses pengupasan kulit luarnya dan direndam dalam air agar ubi jalar tidak browning. Selanjutnya ubi jalar tersebut dirajang tipis-tipis dengan mesin perajang. Proses selanjutnya adalah dikeringkan dalam oven untuk mempersingkat waktu dengan suhu $55-60^{\circ} \mathrm{C}$ dalam 5 jam sudah dapat ditepungkan. Penepungan ubi jalar yang sudah kering dilakukan dengan menggunakan mesin penggiling kemudian hasilnya diayak dengan saringan 100 mesh. Tepung daun kelor dan kacang hijau prosesnya hampir sama yaitu dengan sortasi biji terlebih dahulu kemudian dicuci untuk menghilangkan kotoran. Biji yang sudah bersih direndam dalam air dengan perbandingan air dan kacang 3:1 selama 24 jam sampai biji berkecambah dan dilanjutkan dengan penirisan selama 5 menit. Biji kecambah dikukus pada suhu $90^{\circ} \mathrm{C}$ selama 15 menit dilanjutkan dengan pengupasan kulit, karena kacang hijau yang digunakan merupakan kacang hijau kupas tanpa kulit maka proses pengupasan tidak perlu dilakukan. Kacang hijau atau daun kelor bersih (tanpa kulit) siap dikeringkan pada oven dengan suhu $60^{\circ} \mathrm{C}$ selama 5 jam. Biji kering digiling pada mesin penggiling, dilanjutkan dengan pengayakan menggunakan saringan ukuran 100 mesh.

\section{Tahap Pembuatan Foodbar}

Pembuatan foodbar, tepung ubi jalar kuning, kacang hijau dan daun kelor disangrai sebagai tahapan awal proses gelatinisasi untuk menghindari rasa berpasir pada produk akhir.

Homogenisasi dengan menggunakan mixer kecepatan rendah, pencampuran awal adalah margarin dan gula sampai warna berubah pucat. Bahan-bahan lain ditambahkan, kemudian mixer sampai adonan kalis. Pemipihan adonan dengan ketebalan mencapai $\pm 2 \mathrm{~cm}$, untuk mempercepat pengovenan karena luas permukaan diperbesar. 
Pemanggangan dengan menggunakan oven pada suhu $100^{\circ} \mathrm{C}$ selama 60 menit untuk menurunkan kadar air dengan meminimalisir kehilangan nutrisi dan pematangan adonan. Penghancuran dengan blender dari biskuit yang dihasilkan untuk pengecilan ukuran. Pencetakan dengan menggunakan press hidrolik untuk mendapatkan bentuk yang diinginkan.

Pengamatan yang dilakukan pada penelitian ini meliputi, sifat fisik meliputi kadar air, ekspansi volume, densitas kamba dan tekstur foodbar.

\section{HASIL DAN PEMBAHASAN}

\section{Kadar Air Tepung}

Data hasil penelitian kadar air ubi jalar kuning, kacang hijau dan daun kelor dapat dilihat pada Gambar 1. Kadar air yang tertinggi dihasilkan oleh tepung kacang hijau yaitu rata-rata $8.13 \%$ bb, sedangkan yang terendah dihasilkan oleh ubi jalar kuning rata-rata sebesar $6.83 \%$ bb dan tepung daun kelor sebesar $7.61 \%$ bb. Nilai rata-rata kadar air basis basah yang dihasilkan berbeda-beda tiap jenis tepungnya. Hal itu, dikarenakan kadar air yang dimiliki bahan baku dasar ubi jalar kuning dan daun kelor itu sendiri lebih rendah dibandingkan dengan bahan kacang hijau.

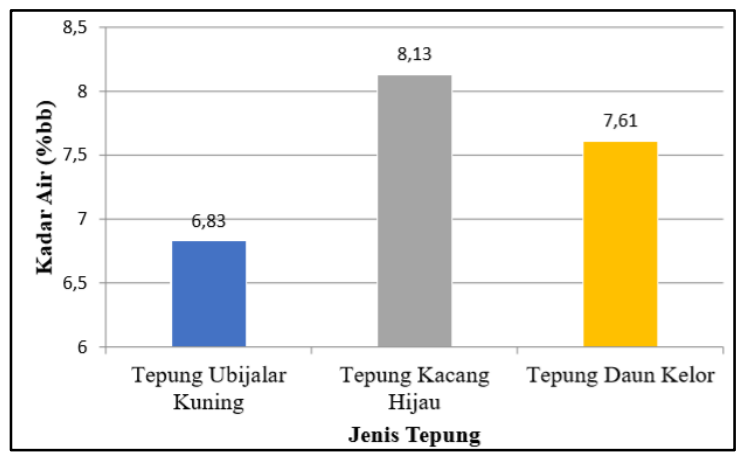

Gambar 1. Kadar air pada setiap tepung

Nilai kadar air ubi jalar kuning tersebut tidak berbeda jauh dengan hasil penelitian Widowati (2006), yang menyatakan bahwa kadar air umbi segar sekitar 60-70\%. Sedangkan, nilai kadar air ubi jalar yang dikeringkan dengan cara dijemur atau menggunakan alat pengering sampai kadar air 10-12 $\%$. Hasil analisa Fitriyati (2006), kadar air tepung ubi jalar kuning adalah $6.77 \%$.

Susanto dan Saneto (1994) menyatakan, pembuatan tepung kacang hijau meliputi perendaman, pengukusan dan pengeringan. Kadar air biji kacang hijau saat perendaman dengan perbandingan air 3:1 menjadi lebih tinggi dibanding bahan baku, yaitu antara 51 - $60 \%$ bb dengan ratarata $54.8 \%$ bb. Kadar air biji kacang hijau kukus tidak kalah tinggi, antara $62.43-68.11 \%$ bb dengan rata-rata $65.8 \%$ bb. Menurut Sunantara (2000), kadar air biji kacang hijau seharusnya 8 - 9\%bb. Biji kacang hijau yang telah dikukus selama 15 menit kemudian dikeringkan dengan menggunakan oven suhu 55 - 60 0C selama 4-5 jam, sehingga kadar air biji kacang hijau menjadi 9.28 - $11.98 \%$ bb dan ratarata kadar air $10.202 \%$ bb. Tepung kacang hijau yang dianjurkan oleh SNI 01-3728-1995 adalah kadar air maksimal 10\%bb dan tepung kacang hijau yang dari penelitian memiliki kadar air sebesar 8.04 $\%$ bb.

Kadar air daun kelor berdasarkan hasil penelitian nilai terendah adalah $71.50 \%$ bb dan tertinggi $78.66 \%$ bb. Rata-rata kadar air daun kelor dalam penelitian ini adalah $74.92 \%$ bb. Kadar air daun kelor menyusut berkisar antara 9.61 - 22.35 \%bb dengan rerata kadar air $17.67 \%$ bb. Menurut Fugli (2001) daun kelor memiliki kadar air 75\%bb sedangkan tepung daun kelor memiliki kadar air 7,5\%bb. Sementara itu peneliti memperoleh kadar air dari daun kelor yaitu dengan rerata $74.92 \%$ bb dan dan kadar air tepung daun kelor yaitu $7.61 \%$ bb.

Faktor-faktor yang menyebabkan adanya perbedaan hasil analisa dengan studi literatur antara lain adanya perbedaan bahan baku yang digunakan, proses pengeringan dan penepungan. Proses pengolahan seperti lama pengukusan, pengirisan dan cara pengeringan berpengaruh nyata terhadap nilai mutu tepung yang dihasilkan.

\section{Kadar Air Foodbar}

Kadar air mempengaruhi ketahanan suatu bahan pangan baik yang mengandung cukup banyak air maupun yang kering. Kadar air yang terlalu tinggi pada bahan pangan akan membuat daya simpannya menjadi rendah karena mudah menjadi media tumbuhnya jamur dan mikrooganisme lainnya. Pengukuran kadar air foodbars dilakukan setelah proses pengovenan.

Analisa kadar air dilakukan dengan metode oven pada suhu $105^{\circ} \mathrm{C}$ selama \pm 24 jam. Besarnya nilai kadar air foodbar yang dihasilkan dapat dilihat pada Lampiran 5. Dari hasil penelitian

diperoleh nilai kadar air produk berkisar antara $2.45 \%$ hingga $3.167 \%$. Diagram batang perbandingan besar kadar air foodbar ditunjukkan oleh Gambar 2.

Hasil pengamatan rerata kadar air menunjukkan adanya kecenderungan terjadinya kenaikan kadar air dengan semakin tingginya kadar porang yang ditambahkan. Hal ini disebabkan oleh jumlah porang yang terperangkap dalam sistem akan semakin banyak dengan semakin besarnya kadar porang dalam sistem bahan. Selain itu dapat dilihat juga bahwa kecenderungan antara kadar air foodbar yang dihasilkan sama dengan hasil yang didapatkan pada adonan. 


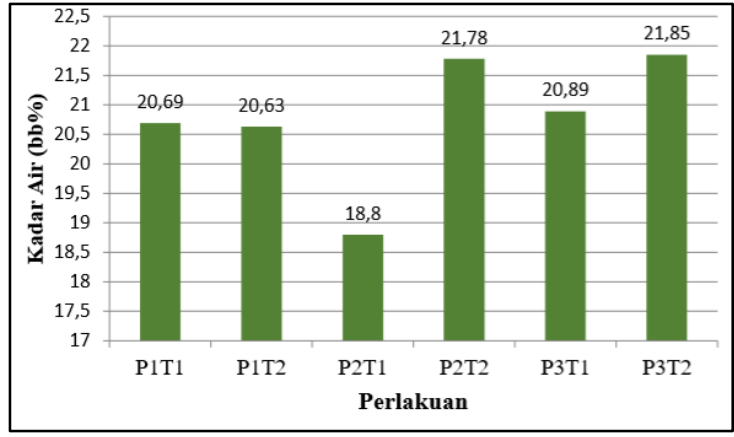

Gambar 2. Kadar air foodbar pada setiap perlakuan

Keterangan:

P1T1 = tepung ubi jalar kuning 100 gram, tepung kacang hijau 60 gram, tepung daun kelor 40 gram, dan tepung porang 4 gram

P1T2= tepung ubi jalar kuning 100 gram, tepung kacang hijau 60 gram, tepung daun kelor 40 gram, dan tepung porang 8 gram

P2T1= tepung ubi jalar kuning 100 gram, tepung kacang hijau 50 gram, tepung daun kelor 50 gram, dan tepung porang 4 gram

P2T2 = tepung ubi jalar kuning 100 gram, tepung kacang hijau 50 gram, tepung daun kelor 50 gram, dan tepung porang 8 gram

P3T1=tepung ubi jalar kuning 100 gram, tepung kacang hijau 40 gram, tepung daun kelor 60 gram, dan tepung porang 4 gram

P3P2=tepung ubi jalar kuning 100 gram, tepung kacang hijau 40 gram, tepung daun kelor 60 gram, dan tepung porang 8 gram

Menurut Wijanarko (2007), karbohidrat yang mengandung pati mampu mengikat air sehingga meningkatkan jumlah molekul air yang tertahan selama pemanggangan. Pada pembuatan foodbars air yang ditambahkan hanya sedikit sehingga gelatanisasi terjadi secara parsial. Sedangkan gelatanisasi sempurna memerlukan jumlah air yang lebih banyak. Muchtadi dan Sugiono (1992) menyatakan bahwa granula pati yang mengalami kerusakan akan menyerap air lebih banyak dari pada granula pati yang tidak rusak. Granula pati yang tidak rusak mampu menyerap air sebanyak $30 \%$ dari beratnya, sementara granula pati yang rusak bisa menyerap air 10 kali dari jumlah tersebut.

Hal ini diperkuat oleh Heriyanto dan Winarto (1999) menyatakan bahwa granula pati dapat mengalami kerusakan selama proses penepungan. Granula pati yang rusak dapat menyerap air hingga lima kali lipat. Selain itu granula pati yang rusak akan lebih cepat menyerap air dibandingkan dengan granula pati yang tidak rusak. Selain itu sistem matriks pati-protein yang terbentuk juga mempengaruhi kadar air produk. Semakin kuat sistem matriks pati-protein yang terbentuk, maka sistem gel yang terbentuk mampu memperangkap air lebih banyak.

\section{Koefisien Ekspansi Volume Foodbar}

Perhitungan volume pengembangan diketahui dengan mencari nilai koefisien ekspansi volume $(\beta)$ dilakukan sesuai Persamaan 1. Hasil penelitian menunjukkan nilai koefisien ekspansi volume produk foodbarss berkisar antara $0.0038 /{ }^{\circ} \mathrm{C}$ - 0.0078/ $/{ }^{\circ}$ C. Pada Gambar 3 menunjukkan grafik perbandingan pengembangan volume pada berbagai perlakuan dalam penelitian.

$$
\Delta \mathrm{V}=\beta . \mathrm{V} 0 . \Delta \mathrm{t}
$$

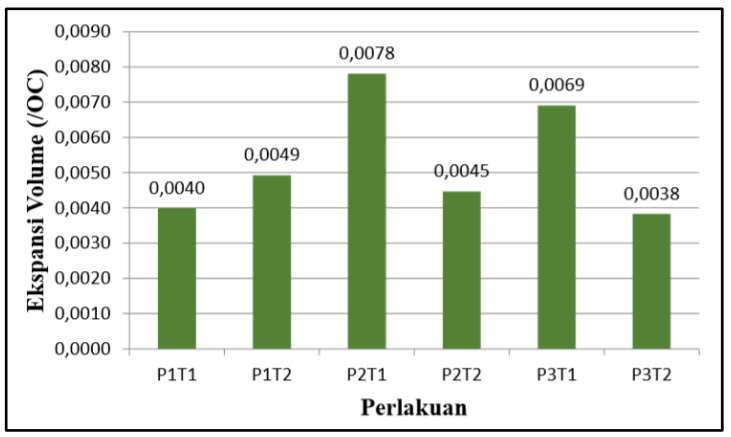

Gambar 3. Nilai ekspansi volume foodbar

Pada grafik menunjukkan nilai ekspansi volume tertinggi didapatkan oleh perlakuan P2T1 dengan komposisi tepung ubi jalar kuning 100 gram, tepung kacang hijau 50 gram, tepung daun kelor 50 gram, dan tepung porang 4 gram yaitu sebesar $0.0078 /{ }^{\circ} \mathrm{C}$. Sedangkan pada perlakuan P3T2 dengan komposisi tepung ubi jalar kuning 100 gram, tepung kacang hijau 40 gram, tepung daun kelor 60 gram, dan tepung porang 8 gram, menunjukkan nilai ekspansi volume terendah sebesar $0.0038 /{ }^{\circ} \mathrm{C}$.

Koefisien nilai ekspansi volume dipengaruhi oleh volume awal (V0), volume akhir (V), suhu sebelum (T0) dan sesudah dioven (T) pada foodbars. Suhu awal foodbars dipengaruhi oleh suhu tepung yang di mixing sebelumnya. Pengembangan nilai volume yang semakin rendah mengindikasikan kondisi foodbar yang semakin keras. Tepung ubi jalar kuning tidak mengandung gluten oleh karenanya semakin banyak jumlah tepung ubi jalar kuning yang digunakan menyebabkan nilai volume pengembangan semakin rendah.

Penambahan tepung ubi jalar kuning pada setiap formulasi pada penelitian ini sama yaitu 100 gram, oleh karena itu pengaruh ini tidak terlihat secara nyata. Baking powder juga mempengaruhi pengembangan volume, baking powder merupakan leavening agent, yaitu bahan yang dapat melepaskan gas karbondioksida $\left(\mathrm{CO}_{2}\right)$ pada kondisi tertentu. Bahan ini menciptakan gelembung gas pada adonan dan membuat adonan mengembang. Ketika produk tersebut dipanaskan akan terbentuk kantungkantung udara yang mengakibatkan produk terasa ringan dan renyah (Yuwono dan Susanto, 1998). Pada penelitian ini penambahan baking powder sebesar $2 \%$ bb dari total tepung yang digunakan. Selama pemanggangan, volume gas bersama dengan 
udara dan uap air yang terperangkap dalam adonan akan mengembang (Susanto dan Saneto, 1994).

\section{Densitas Kamba Foodbar}

Perhitungan penelitian densitas kamba foodbar, pertama nilai massa adonan dibuat sama yaitu sebelum dioven yaitu 40 gram untuk semua perlakuan, sesudah dioven ditimbang lagi foodbar yang terbentuk.

Data densitas dan hasil analisis foodbar ubi jalar kuning pada setiap volume air yang digunakan untuk mengukur volume foodbar juga sama yaitu $200 \mathrm{ml}$ pada beaker glass, volume air yang dipindahkan (volume bahan) berbeda-beda pada setiap perlakuan. Perlakuan dapat dilihat pada Gambar 4 menunjukkan perbandingan rata-rata densitas foodbar pada berbagai perlakuan.

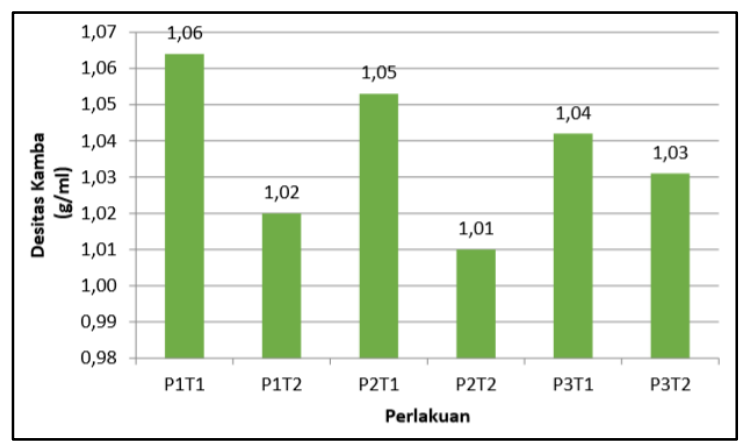

Gambar 4. Nilai densitas kamba foodbar

Pada Gambar 4, kecenderungan penurunan densitas kamba pada foodbar terjadi seiring dengan peningkatan penambahan kadar porang. Semakin besarnya air yang dapat diabsorpsi oleh produk foodbar ini, menjadikan jarak antara molekul penyusun menjadi semakin besar mengakibatkan kohesifitasnya menurun sehingga ketahanan produk juga menurun.

Penurunan densitas kamba foodbar juga terjadi dengan adanya peningkatan suhu pemanasan. Hal ini disebabkan adanya meningkatan laju evaporasi dengan terjadinya peningkatan suhu pemanasan oven dari $100^{\circ} \mathrm{C}$ menjadi $135^{\circ} \mathrm{C}$ dengan lama 25 menit. Semakin besarnya air yang diuapkan pada suhu pemanasan $135^{\circ} \mathrm{C}$ dibandingkan pada suhu pemanasan $100^{\circ} \mathrm{C}$, maka berat produk per satuan volume akan semakin rendah yang menghasilkan densitas kamba produk foodbar yang lebih rendah.

\section{Tekstur Foodbar}

Tekstur foodbar sebelum dioven, sesudah dioven diukur dengan mengambil 3 titik yang berbeda kemudian dicari rata-rata untuk dimasukkan dalam perhitungan. Tekstur foodbar sebelum dioven, sesudah dioven ditunjukkan Gambar 5.

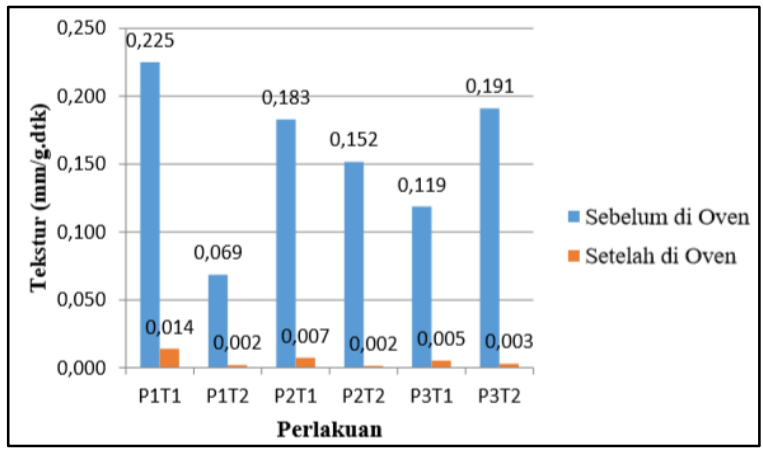

Gambar 5. Nilai tekstur foodbar

Tekstur foodbar dari Gambar 4 di atas semakin kecil sesudah dioven dengan perbedaan yang cukup jauh. Hal ini dikarenakan sebelum dioven foodbar masih lembek sehingga teksturnya lunak yaitu $0.156 \mathrm{~mm} / \mathrm{g}$.dtk, kadar air foodbar sebelum dioven dalam pembahasan sebelumnya juga menunjukkan nilai yang lebih besar. Sesudah dioven tekstur foodbar hanya $0.006 \mathrm{~mm} / \mathrm{g}$.dtk

\section{PENUTUP}

Kesimpulan

Berdasarkan hasil penelitian dapat disimpulkan bahwa perlakuan penambahan tepung dan porang dengan komposisi tertentu memberikan pengaruh nyata terhadap kadar air, ekspansi volume, densitas kamba, dan tekstur foodbar.

Berdasarkan hasil pengujian fisik perlakuan terbaik pada foodbar pada kombinasi perlakuan 100 gram tepung ubi jalar kuning (40 gram) tepung kacang hijau (60 gram) tepung daun kelor dan (4\%) porang (P3T1). Hasil perlakuan paling tidak baik ditunjukkan pada kombinasi perlakuan 100 gram tepung ubi jalar kuning (60 gram) tepung kacang hijau (40 gram) tepung daun kelor dan $(8 \%)$ porang (P1T2).

\section{REFERENSI}

Antarlina, S.S. 1991. Pengaruh Umur Panen dan Klon terhadap Beberapa Sifat Sensoris, Fisis dan Kimiawi Tepung Ubi Jalar. Thesis S-2. Fakultas Pasca Sarjana UGM. Program KPK UGM-Unibraw. (tidak diterbitkan) : Yogyakarta

Arifin, M.A. 2001. Pengeringan Keripik Umbi IlesIles Secara Mekanik untuk Meningkatkan Mutu Keripik Iles-Iles. Tesis Teknologi Pasca Panen. PPS. IPB:Bogor

Astawan, M. 2004. Kacang Hijau Sebagai Antioksidan. http://cyberman.cbn.net.id/ detilhit.asp?kategori=health\&newsno $=472$. Tanggal akses 15 Juli 2009: Malang

Becker, K. 2003. Moringa oleifera: An Underutilised with Amazing Versatility. 
Depart. of Aquaculture Systems and Animal Nutritions. University of Hohenheim. Germany

Datrex. 2009. Food Bars VS Canned Goods. http://www.survivalinstinct.com/ mayday food bars.html. Tanggal akses 3 Agustus 2009: Malang

Eri, R.A.P. 2007. Karakteristik Fisik Kimia Tepung Porang (Amorphophallus oncophyllus) Hasil Fraksinasi dengan Metode Hembusan (Blower). Skripsi Jurusan Teknologi Hasil Pertanian. Fakultas Teknologi Pertanian. Universitas Brawijaya: Malang

Fellows, P.J. 1990. Food Processing and Technology:Principles and Practices. Ellis Harwood: New York

Fitriyati, V. 2006. Pengaruh Konsentrasi Natrium Metabisulfit \& Suhu Pengeringan Terhadap Karakteristik Fisik, Kimia dan Amilografi Tepung Ubi Jalar Jepang (Shiroyutaka). Skripsi. Teknologi Hasil Pertanian. Unila. Lampung

Fuglie, L.G. 2001. The Miracle Tree. The Multiple Attributes of Moringa. CTA, Wageningen, The Netherlands.

Liz. 2009. Emergency Food Bars. http://www.survivaltopics.com/survival/eme rgency-foodbars/"> $>$ Emergency Food Bars $<\mathrm{a} />$. Tanggal Akses 3 Agustus 2009: Malang

Maltz, S.A. 1992. Cookie and Crackers Technology. The AVI Publishing Company Inc:London

Muchtadi, D dan Sugiono. 1992. Teknolohi Pengolahan Pangan Nabati. Pusat Antar Universitas (PAU) Pangan dan Gizi. IPB: Bogor
Richter N., P. Siddhuraju, K. Becker. 2002. Nutritional Quality Evaluation of Moringa (Moringa oleifera Lam) Leaves as An Alternative Protein Source of Tilapia. University of Hohenheim. Germany.

Sholeh. 2009. Proses Penyangraian dan Penggoreng. http://smkn1skrbjbr.blogspot.com /2009_03_01_archive.html. Tanggal akses 27 Agustus 2012/ : Malang

Sunantara, I.M.M. 2000. Teknik Produksi Benih Kacang Hijau. Instalasi Penelitian dan Pengkajian Teknologi Pertanian Denpasar: Bali

Suprapti, L. 2003. Studi Karakteristik Sifat Fisik dan Kimia Tepung Beberapa Varietas Ubi Jalar (Ipomoea batatas L). Skripsi tidak diterbitkan. Jurusan Teknologi Hasil Pertanian. Fakultas Teknologi Pertanian Universitas Brawijaya : Malang

Susanto, T dan B, Saneto. 1994. Teknologi Pengolahan Hasil Pertanian. PT. Bina Ilmu: Surabaya

Wang, W dan A, Johnson. 2007. Konjac_An Introduction. http://www.cybercoloids.net /library/konjac/introduction.php. Tanggal akses 15 Juli 2009 : Malang

Widowati, S. 2009. Tepung Aneka Umbi Sebuah Solusi Ketahanan Pangan. Tabloid Sinar Tani terbit pada 6 Mei 2009.

Wijanarko, S.B. 2007. Pengembangan Prototipe Pangan Darurat Berenergi Tinggi dan Padat Nutrisi Berbasis Potensi Lokal. Badan Penelitian dan Pengembangan Pertanian. Universitas Brawijaya: Malang 